\title{
COMBINED THERAPY WITH m-TOR-DEPENDENT AND -INDEPENDENT AUTOPHAGY INDUCERS CAUSES NEUROTOXICITY IN A MOUSE MODEL OF MACHADO-JOSEPH DISEASE
}

\author{
S. DUARTE-SILVA, A. SILVA-FERNANDES, \\ A. NEVES-CARVALHO, C. SOARES-CUNHA, \\ A. TEIXEIRA-CASTRO AND P. MACIEL * \\ Life and Health Sciences Research Institute (ICVS), School of \\ Health Sciences, University of Minho, Braga, Portugal \\ ICVS/3B's - PT Government Associate Laboratory, \\ Braga/Guimarães, Portugal
}

\begin{abstract}
A major pathological hallmark in several neurodegenerative disorders, like polyglutamine disorders (polyQ), including Machado-Joseph disease (MJD), is the formation of protein aggregates. MJD is caused by a CAG repeat expansion in the ATXN3 gene, resulting in an abnormal protein, which is prone to misfolding and forms cytoplasmic and nuclear aggregates within neurons, ultimately inducing neurodegeneration. Treatment of proteinopathies with drugs that up-regulate autophagy has shown promising results in models of polyQ diseases. Temsirolimus ( $\mathrm{CCl}-779)$ inhibits the mammalian target of rapamycin (m-TOR), while lithium chloride ( $\mathrm{LiCl}$ ) acts by inhibiting inositol monophosphatase, both being able to induce autophagy. We have previously shown that chronic treatment with $\mathrm{LiCl}(10.4 \mathrm{mg} / \mathrm{kg})$ had limited effects in a transgenic MJD mouse model. Also, others have shown that $\mathrm{CCl}-779$ had mild positive effects in a different mouse model of the disease. It has been suggested that the combination of mTOR-dependent and -independent autophagy inducers could be a more effective therapeutic approach. To further explore this avenue toward therapy, we treated CMVMJD135 transgenic mice with a conjugation of $\mathrm{CCl}-779$ and $\mathrm{LiCl}$, both at concentrations known to induce autophagy and not to be toxic. Surprisingly, this combined treatment proved to be deleterious to both wild-type (wt) and transgenic animals, failing to rescue their neurological symptoms and actually exerting neurotoxic effects. These results highlight the possible dangers of manipulating autophagy in the nervous system and suggest that a better understanding of the potential disruption in the autophagy pathway in MJD is required before successful long-term autophagy modulating therapies can be developed. (c) 2015 IBRO. Published by Elsevier Ltd. All rights reserved.
\end{abstract}

${ }^{*}$ Correspondence to: P. Maciel, Life and Health Sciences Research Institute (ICVS), School of Health Sciences, ICVS/3B's - PT Government Associate Laboratory, University of Minho, Campus Gualtar, 4710-057 Braga, Portugal. Tel: +351-253-604824; fax: +351-253-604820.

E-mail address: pmaciel@ecsaude.uminho.pt (P. Maciel).

Abbreviations: EM, electron microscopy; FDA, Food and Drug Administration; HD, Huntington disease; $\mathrm{LiCl}$, lithium chloride; MJD, Machado-Joseph disease; mTOR, mammalian target of rapamycin; NGM, nematode growth medium; polyQ, polyglutamine disorders; SCA, Spinocerebellar Ataxia type; wt, wild-type.
Key words: polyglutamine diseases, animal models, ataxia, behavior, therapy, autophagy.

\section{INTRODUCTION}

Machado-Joseph disease (MJD), also known as Spinocerebellar Ataxia type 3 (SCA3), is the most common autosomal dominant ataxia worldwide (Maciel et al., 1995), and is caused by a CAG repeat expansion within the coding region of the ATXN3 gene (Kawaguchi et al., 1994). The clinical severity and the age at onset of the disease depend on the length of the expanded repeat (Paulson, 1999; Gusella and MacDonald, 2000). MJD is characterized by motor uncoordination and amyotrophy, spasticity, gait ataxia, difficulty with speech and swallowing, altered eye movements, double vision, and frequent urination (Coutinho and Sequeiros, 1981; Sequeiros and Coutinho, 1993).

MJD shares many features with other polyglutamine diseases, such as the formation of cytoplasmic and nuclear inclusion bodies within neurons by the mutant protein (Becher et al., 1998; Wolozin and Behl, 2000). It is assumed that the common toxic gain-of-function mechanisms for the polyglutamine-containing protein depend on aggregation and deposition of misfolded proteins leading to neuronal dysfunction and eventually cell death (Winklhofer et al., 2008).

Despite the well-described clinical and pathological phenotypes, the molecular and cellular events underlying neurodegeneration in these disorders are still poorly understood. Compelling evidence points to major etiological roles for interference with transcriptional regulation, protein aggregation and clearance, the ubiquitin-proteasome system and alterations of calcium homeostasis in the neuronal loss observed during the neurodegenerative process. These pathways could act independently or, more likely, interact and enhance each other, triggering the accumulation of cellular damage that eventually leads to dysfunction and death (Duenas et al., 2006). This suggests that simultaneous targeting of several pathways may be therapeutically necessary to prevent neurodegeneration and preserve neuronal function. Understanding how dysregulation of these pathways mediates disease progression is leading to the first attempts of obtaining effective therapeutic strategies in vivo, which may prove beneficial in the treatment of polyglutamine disorders (polyQ). One such pathway is autophagy, a process that encompasses lyso- 
somal degradation of cytoplasmic material, such as defective organelles and unfolded/aggregated proteins. Autophagy is morphologically defined by the appearance of numerous cytosolic autophagosomes, which are formed by the assembly and expansion of double layered, membrane bound structures of unknown origin around whole organelles and isolated proteins. The autophagosomes encapsulate cytosolic materials and subsequently dock and fuse with lysosomes or other vacuoles, resulting in the degradation of their contents (Kelekar, 2005). In several neurological diseases, the pathological accumulation of autophagosomes/autophagosome-like structures and abnormalities in the endosomal-lysosomal pathway have been documented by electron microscopy (EM) in human post mortem brain tissue (Cataldo et al., 1996; Anglade et al., 1997; Nixon et al., 2005; Yu et al., 2005; Moreira et al., 2007). While initially this was interpreted as evidence of death triggered by autophagy, the currently predominant perspective is that this vesicle accumulation reflects impaired autophagy completion, which is emerging as a common element to several neurodegenerative disorders (Boland et al., 2008; MartinezVicente et al., 2010). Autophagy induction has therefore been advanced as a promising therapeutic strategy for these diseases (Menzies et al., 2010; Spilman et al., 2010), and in the particular case of MJD, genetic approaches in lentiviral overexpression models have supported this conclusion (Nascimento-Ferreira et al., 2011).

The mammalian target of rapamycin (mTOR) kinase is a master negative regulator of autophagy (Levine and Klionsky, 2004). mTOR is a central sensor of energy status, growth factors and nutrient signals, and can be inhibited by rapamycin (Rubinsztein et al., 2007) and related small molecules (Zhang et al., 2007). Besides this pathway, autophagy can also be regulated independently of mTOR (Sarkar et al., 2005). Inhibition of inositol monophosphatase (IMPase) reduces free inositol and IP3 levels, which leads to an upregulation of autophagy. Rapamycin has been shown to reduce aggregation of expanded polyQ in transfected cells (Ravikumar et al., 2002), to protect against neurodegeneration in a fly model of Huntington disease (HD), and to improve motor performance and decrease aggregate formation in a mouse model of HD (Ravikumar et al., 2004). Lithium chloride ( $\mathrm{LiCl}$ ), an mTOR-independent autophagy inducer has been shown to improve motor performance and depressive-like behavior in a mouse model of HD, as well as to improve neuropathology and motor function in a SCA1 mouse model (Wood and Morton, 2003; Watase et al., 2007). We have recently shown that 19 weeks of $\mathrm{LiCl}(10.4 \mathrm{mg} / \mathrm{kg})$ treatment in the CMVMJD135 mouse model, had limited effects on the motor phenotype of these animals, despite its ability to induce autophagy both in the chronic and acute treatment (Duarte-Silva et al., 2014). CCl-779, a less toxic rapamycin analogue, was recently approved by the Food and Drug Administration (FDA) for the treatment of renal cell carcinoma (Kwitkowski et al., 2010; Bergmann et al., 2014). This drug was shown to reduce mutant ataxin-3 levels and toxicity, as well as ameliorate the disease symptoms in a transgenic mouse model of MJD (Menzies et al., 2010). Additionally, Menzies and colleagues suggested that the use of combined $\mathrm{LiCl}$ and $\mathrm{CCl}-779$ would be an interesting approach to explore (Sarkar et al., 2009). The theoretical basis for this combinatory approach would be the fact that $\mathrm{LiCl}$ can act both as an autophagy inducer or inhibitor, depending on the dose used (Stambolic et al., 1996; Sarkar et al., 2005). At higher dosages $\mathrm{LiCl}$ is actually able to inhibit GSK3, which suppresses autophagy via phosphorylation of mTOR (Stambolic et al., 1996; Chiu and Chuang, 2010); thus, a combinatory therapy with another mTOR-dependent autophagy inducer could counteract this effect. The main goal of this work was to test the potential of this combinatory treatment in MJD. We treated transgenic models of MJD in Caenorhabditis elegans and mouse (Teixeira-Castro et al., 2011; SilvaFernandes et al., 2014b) with a combination of CCl-779 and $\mathrm{LiCl}$ (m-TOR-dependent and independent pathways, respectively). We show that the combinatory treatment using $\mathrm{LiCl}$ and $\mathrm{CCl}-779$ improved locomotion defects in the transgenic $C$. elegans model of MJD. However, our results show that the simultaneous administration of $\mathrm{LiCl}$ and $\mathrm{CCl}-779$ was ineffective in rescuing the motor impairments of CMVMJD135 mice and had deleterious effects both in CMVMJD135 and wild-type (wt) animals at the doses used in this pre-clinical trial.

\section{EXPERIMENTAL PROCEDURES}

\section{Nematode strains and general methods}

Standard methods were used for culturing and observing C. elegans (Brenner, 1974). Briefly, nematodes were grown on nematode growth medium (NGM) plates seeded with Escherichia coli OP50 strain at $20^{\circ} \mathrm{C}$. The transgenic AT3q130 strain used in this work was previously described by Teixeira-Castro et al. (2011). All assays were performed at room temperature $\left(20^{\circ} \mathrm{C}\right)$ on 4-day-old synchronized animals grown at $20^{\circ} \mathrm{C}$.

\section{C. elegans drug treatment and motility assay}

AT3q130 animals were grown in liquid culture in a 96-well plate format, with the combination of $\mathrm{LiCl}$ and $\mathrm{CCl}-779$. Four-day-old animals were transferred from the 96-well plates onto an unseeded NGM plate (equilibrated at $20^{\circ} \mathrm{C}$ ). Plates were allowed to dry for $1 \mathrm{~h}$ before starting the assays. Motility assays were performed at $20^{\circ} \mathrm{C}$ as previously described (Gidalevitz et al., 2006; TeixeiraCastro et al., 2011). Animals remaining inside a 1-cm circle after one min were scored as locomotion defective. Motor behavior assays were run in triplicates or quadruplicates ( $n=3$ or 4 ), with a total of at least 150 animals tested per compound concentration. Compound preparation: Stock solution of $200 \mathrm{mM} \mathrm{LiCl} \mathrm{(1.05679-0100,}$ Merck, Darmstadt, Germany) was prepared in water. CCl-779 (T8040, LC-laboratories, Woburn, MA, United States) $48.5 \mathrm{mM}$ stock solution was prepared in $\mathrm{EtOH}$. 


\section{Ethics statement}

All procedures with mice were conducted in accordance with European regulations (European Union Directive 2010/63/EU). Animal facilities and the people directly involved in animal experiments (S.D.S., A.N.C.) were certified by the Portuguese regulatory entity-Direcção Geral de Alimentação e Veterinária.

All the protocols performed were approved by the Animal Ethics Committee of the Life and Health Sciences Research Institute, University of Minho.

\section{Mouse strains, maintenance and general methods}

In this study we used male CMVMJD135 mice (background C57BL/6) (Silva-Fernandes et al., 2014a). Transgenic and wt drug- and placebo-treated animals were sequentially assigned and housed at weaning in groups of five animals in filter-topped polysulfone cages $267 \times 207 \times 140 \mathrm{~mm}\left(370 \mathrm{~cm}^{2}\right.$ floor area) (Tecniplast, Buguggiate, Italy), with corncob bedding (Scobis Due, Mucedola SRL, Settimo Milanese, Italy) in a conventional animal facility. The progeny produced by mating MJD transgenic with wild-type animals were genotyped by PCR, as previously described (Silva-Fernandes et al., 2010). The experiment started at 4 weeks and ended at 24 weeks of age. The experimenter was not blind to the study. All animals were maintained under standard laboratory conditions: an artificial 12-h light/dark cycle (lights on from 8:00 to 20:00 h), with an ambient temperature of 21 $\pm 1^{\circ} \mathrm{C}$ and a relative humidity of $50-60 \%$; the mice were given a standard diet (4RF25 during the gestation and postnatal periods, and 4RF21 after weaning, Mucedola SRL, Settimo Milanese, Italy) and water ad libitum. Health monitoring was performed according to FELASA guidelines (Nicklas et al., 2002), confirming the Specified Pathogens status of sentinel animals maintained in the same animal room. Humane endpoints for the experiment were defined as previously described (Duarte-Silva et al., 2014). The timeline used in this study is shown in Fig. 2A.

\section{Drug treatment}

In order to conduct this pre-clinical trial we used a combination of two FDA-approved compounds, $\mathrm{LiCl}$ (Merck, Darmstadt, Germany) and CCl-779 (LC Laboratories, Woburn, MA, United States). Mice were allocated to vehicle and $\mathrm{LiCl}+\mathrm{CCl}-779$-treated groups (vehicle-treated CMVMJD135, $n=12$; LiCl + CCl-779treated CMVMJD135, $n=10$; vehicle-treated wt, $n=$ 12; $\mathrm{LiCl}+\mathrm{CCl}-779$-treated wt, $n=15)$. The treatment started at the asymptomatic age of 5 weeks. Animals were intraperitoneally injected three times a week in the testing room and immediately placed in their home cage, except in the week of behavioral tests. Transgenic and wt animals were treated with $10.4 \mathrm{mg} / \mathrm{kg}$ of $\mathrm{LiCl}$ and $20 \mathrm{mg} /$ $\mathrm{kg}$ of $\mathrm{CCl}-779$ (doses and routes as previously described by Wood and Morton (2003), Ravikumar et al. (2004), Watase et al. (2007), Duarte-Silva et al. (2014)). LiCl stock solutions were prepared at a concentration of $25 \mathrm{mg} / \mathrm{kg}$ in $0.15 \mathrm{M} \mathrm{NaCl}, 5 \%$ Tween-20 and 5\% PEG 400 and CCl779 at $50 \mathrm{mg} / \mathrm{kg}$ in absolute ethanol. Control animals were given a placebo injection of buffer $(0.15 \mathrm{M} \mathrm{NaCl}, 5 \%$ Tween-20 and 5\% PEG 400) with the same frequency.

\section{Body weight}

All mice were weighed a week before the start of the drug treatment (4 weeks) and then at 8, 12, 16, 20 and 24 weeks of age.

\section{Behavioral tests}

The behavioral tests herein shown were performed as previously described (Duarte-Silva et al., 2014; SilvaFernandes et al., 2014b).

\section{Western-blot}

Mouse brain tissue was prepared as previously described (Duarte-Silva et al., 2014). The conditions used for incubation with primary antibodies are as follows: rabbit anti-p62 (1:50, Abcam, Cambridge, UK) and rabbit antiBeclin-1 (1:1000, Cell signaling, Beverly, MA), mouse anti-beta-actin (Ambion, 1:5000, Life Technologies, CA, USA), rabbit anti-LC3 (1:1000 Novus Biologicals, Littleton, CO) and rabbit anti-ataxin3 serum (1:5000; kindly provided by Dr. Henry Paulson). The secondary antibodies were incubated at the following dilutions: anti-rabbit $(1: 10,000$, Biorad, California, USA) and anti-mouse $(1: 10,000$, Biorad, California, USA). Antibody affinity was detected by chemiluminescence (Clarity ECL kit, Biorad, California, USA). Western-blot quantifications were performed using the Chemidoc XRS Software with ImageLab Software (Biorad, California, USA) according to the manufacturer's instructions and using beta-actin as the loading control.

\section{Immunohistochemistry}

The animals (24-week-old CMVMJD135 LiCl + CCI-779treated and untreated) were deeply anesthetized using a mixture of medetomidine $(0.3 \mathrm{mg} / \mathrm{kg})$ and ketamine hydrochloride $(150 \mathrm{mg} / \mathrm{kg})$ and transcardially perfused with saline $(0.9 \%)$ followed by paraformaldehyde $4 \%$. The brains were extracted and post-fixed with paraformaldehyde for $72 \mathrm{~h}$ and embedded in paraffin using standard procedures. 4- $\mu \mathrm{m}$-thick brain sections were subjected to standard immunohistochemistry procedure. Briefly, the slides were treated with $1 \mathrm{M}$ citrate buffer (antigen retrieval), the endogenous peroxidases were blocked $\left(3 \% \quad \mathrm{H}_{2} \mathrm{O}_{2}\right)$ and then incubated with mouse anti-ATXN3 (1H9, 1:500, MAB5360, Millipore). After several washing steps, the slides were incubated with a biotinylated anti-polyvalent antibody followed by detection using biotin-streptavidin coupled to horseradish peroxidase and the reaction with DAB (3,3'-diaminobenzidine) substrate (Lab Vision ${ }^{\mathrm{TM}}$ Ultra-Vision $^{\mathrm{TM}}$ dectection kit, Thermo Scientific). ATXN3 nuclear inclusions in the pontine nuclei for CMVMJD135treated and -untreated groups ( $n=3$ for each group, four slides per animal) were counted and normalized for total area using the Olympus BX51 stereological 
microscope (Olympus) and Visiopharma integrator system software (Visiopharma).

\section{Statistical analysis}

The experimental unit used in this study was a single animal. Power analysis was used to determine the sample size as previously described (Silva-Fernandes et al., 2014b). The estimates of required number of animals for specific behavioral tests and time-points of analysis are described in (Duarte-Silva et al., 2014). Continuous variables with normal distributions (K-S test $p>0.05$ ) were evaluated with the Student $t$-test or a two-way ANOVA (Factors: genotype and treatment). Behavioral data were analyzed using non-parametric Mann-Whitney $U$-test when variables were noncontinuous or when a continuous variable did not present a normal distribution (Kolmogorov-Smirnov test $p<0.05)$. Contingency tables (Fisher's exact test) were used for categorical variables in the SHIRPA protocol. A one-Way ANOVA was used for paired comparisons. All statistical analyses were performed using SPSS 22.0 (SPSS Inc., Chicago, IL, USA). A critical value for significance of $p<0.05$ was used throughout the study.

\section{RESULTS}

\section{$\mathrm{LiCl}+\mathrm{CCl}-779$ treatment improved locomotion deficits in a transgenic $C$. elegans model of MJD}

We evaluated compound efficacy to rescue neuronal dysfunction in a $C$. elegans model of MJD pathogenesis, in which expression of mutant ATXN3 (AT3q130) in all neuronal cells results in locomotion defects (TeixeiraCastro et al., 2011). AT3q130 animals grown in liquid medium with or without drugs for four days were tested for defects in locomotion, by employing a motility assay. Treatment with $\mathrm{LiCl}$ and $\mathrm{CCl}-779$ resulted in a partial rescue of locomotion impairment (Fig. 1). Taking these

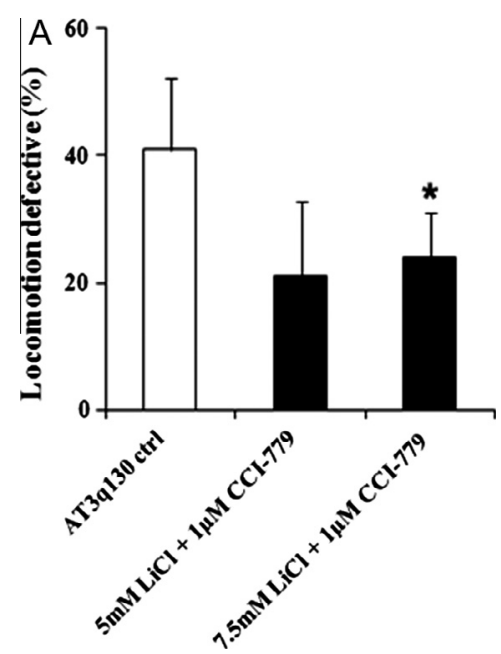

Fig. 1. AT3q130 animals treatment with the small molecules targeting autophagy. (A) AT3q130 animals treated with $7.5 \mathrm{mM}$ of $\mathrm{LiCl}$ $+\mathrm{CCl}-779$ at $1 \mu \mathrm{M}$ showed a significant reduction in locomotion defects given by the motility assay. Data are mean $\pm S D$, at least 150 animals per data point, ${ }^{*} p<0.05$ (One way ANOVA). results in consideration, we pursued with this potential combinatory treatment by performing a pre-clinical trial in an MJD mouse model.

\section{$\mathrm{LiCl}+\mathrm{CCl}-779$ treatment effects in the CMVMJD135 mouse model}

The CMVMJD135 transgenic mice, expressing full-length human ataxin-3 with an expanded polyQ repeat of 135 glutamines ubiquitously and at near endogenous levels, have previously been shown to develop a slowly progressive motor and neuropathological phenotype resembling MJD (Silva-Fernandes et al., 2014a). We treated these mice with $\mathrm{LiCl}+\mathrm{CCl}-779$ at dosages previously described, for each compound individually, to activate autophagy and not to be toxic (10.4 and $20 \mathrm{mg} / \mathrm{kg}$, respectively) (Wood and Morton, 2003; Ravikumar et al., 2004; Duarte-Silva et al., 2014). We started the treatment regimen at 5 weeks of age (one week before the onset of the symptoms) and followed the animals until they reached 24 weeks, performing a monthly extensive characterization of the animals using the SHIRPA protocol and the Beam walk test. The study design is summarized in Fig. 2A. Before the beginning of injections, at 4 weeks of age, mice were evaluated using the SHIRPA protocol, and no differences were observed between wild-type and transgenic animals.

\section{Survival and general health}

Survival is not a useful readout in pre-clinical trials using the CMVMJD135 model, because animals, although very sick, survive until quite late ages; however, during this preclinical trial three transgenic animals treated with $\mathrm{LiCl}$ $+\mathrm{CCl}-779$ died (while none of the untreated animals died, $p=0.006$ ), which we attribute to the toxicity of the compounds when administered together. At the end of the experiment, both CMVMJD135 and wt mice treated with $\mathrm{LiCl}+\mathrm{CCl}-779$ presented an unhealthy appearance, but were still able to move and feed.

Administration of $\mathrm{LiCl}+\mathrm{CCl}-779$ to wt mice caused a significant decrease in the body weight in comparison to the vehicle group $(p=0.002)$. This drug combination treatment also diminished significantly the already reduced body weight of CMVMJD135 mice when compared to the vehicle-treated transgenic group $(p=0.001)$ (Fig. 2B).

\section{SHIRPA protocol}

At $8,16,20$ and 24 weeks of age, we observed a decreased exploratory activity in vehicle-treated CMVMJD135 mice, while transgenic animals treated with $\mathrm{LiCl}+\mathrm{CCl}-779$ showed an increased exploratory activity at 8,16 and 24 weeks of age, given by the significant increase in the number of rears in the viewing jar ( $p=0.001, p=0.04$ and $p=0.003$, respectively), reaching a comparable performance to the wt vehicletreated group (Fig. 3A). However, at eight weeks of age, there was an increase in exploratory behavior in wildtype mice treated with $\mathrm{LiCl}+\mathrm{CCl}-779$, suggesting a non-specific effect (Fig. 3A). CMVMJD135 mice treated 


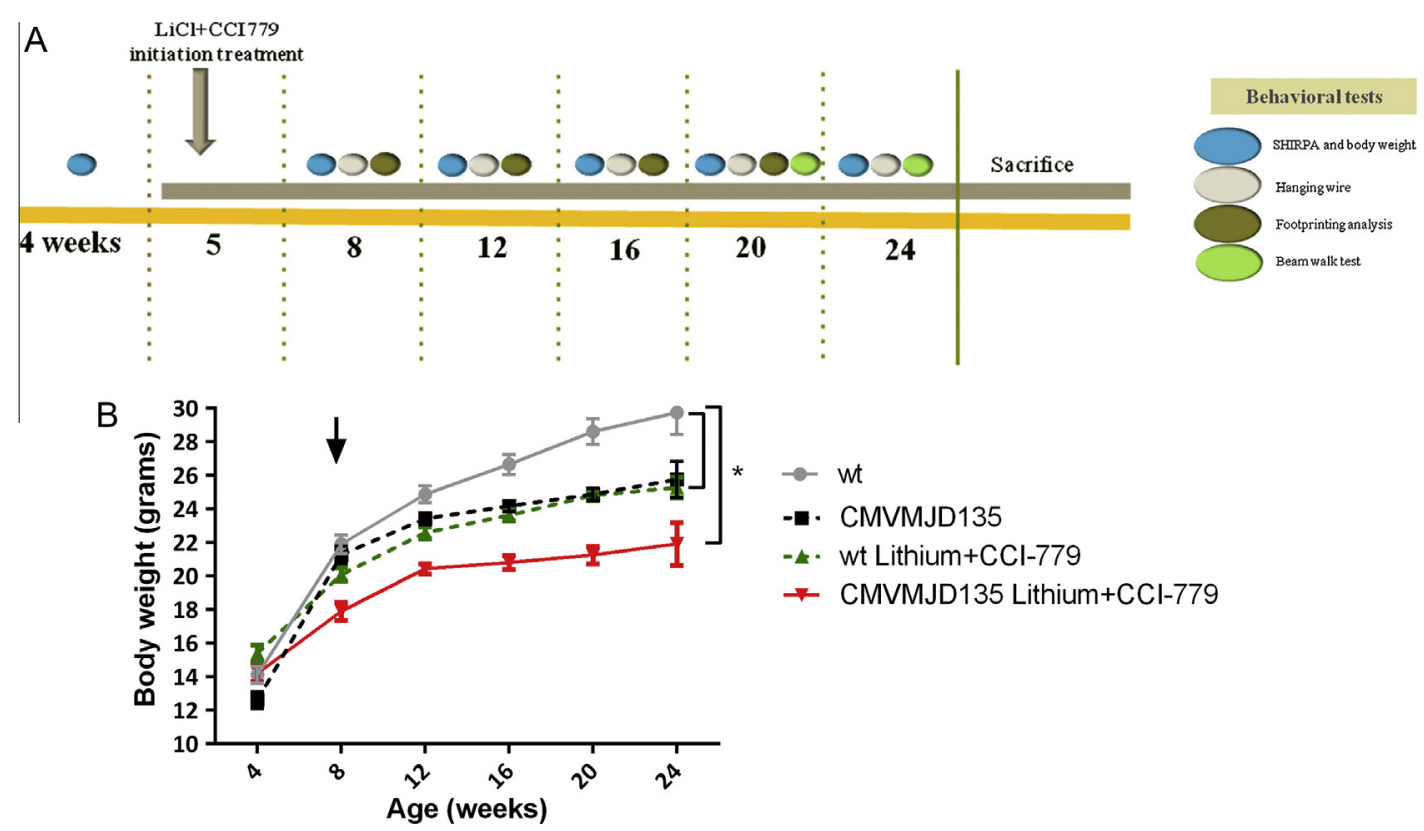

Fig. 2. Effect of $\mathrm{LiCl}+\mathrm{CCl}-779$ treatment on body weight of CMVMJD135 and wild-type mice. (A) Schematic timeline for the behavioral analysis of $\mathrm{LiCl}+\mathrm{CCl}-779$ pre-clinical trial. (B) The body weight in grams between 8 and 24 weeks of age is depicted for wt and CMVMJD135 mice treated with $\mathrm{LiCl}+\mathrm{CCl}-779$ or vehicle ( $n=10-12$ for each group). Symbols represent mean \pm SEM of the different groups. *represents $p<0.05$, for genotype factor (two-way ANOVA). Vertical arrow represents the onset of the phenotype.

with $\mathrm{LiCl}+\mathrm{CCl}-779$ also demonstrated a significant increase in the locomotor activity when compared to vehicle-treated CMVMJD135 animals at 8 and 12 weeks of age $(p=0.022$ and $p=0.016$, respectively $)$ (Fig. 3B). Of notice, at the age of 12 weeks we could not observe statistically significant differences between wt and CMVMJD135 vehicle-treated groups, meaning that the phenotype was not yet installed for these parameters (exploratory behavior and locomotor activity). No positive effect of the $\mathrm{LiCl}+\mathrm{CCl}-779$ treatment was observed in the hanging wire test (grip strength) in CMVMJD135 mice (Fig. 3C). In fact, this combinatory treatment significantly worsened this symptom at 8 weeks of age when comparing untreatedCMVMJD135 with treated mice $(p=0.01)$. Also, the grip strength (hanging wire test) of $\mathrm{LiCl}+\mathrm{CCl}-779$ treated wt animals was always worse than that of vehicle-treated wt animals. Regarding tremors, we observed a slight improvement in CMVMJD135 mice at 24 weeks of age $(p=0.038)$ (Fig. 4A), as seen previously with $\mathrm{LiCl}$ treatment (Duarte-Silva et al., 2014). We observed no therapeutic effect of $\mathrm{LiCl}+$ $\mathrm{CCl}-779$ treatment on gait quality and limb clasping (Fig. 4B, C). The limb clasping reflex increased with disease progression, being statistically different only at 24 weeks of age. Importantly, at 16 and 20 weeks of age, the $\mathrm{LiCl}+\mathrm{CCl}-779$ treatment actually worsened limb clasping in the transgenic animals when compared to CMVMJD135-vehicle animals (Fig. 4C, labeled with \#) $(p=0.05$ and 0.008 , respectively $)$.

\section{Foot printing test}

Footprint patterns of wt and CMVMJD135 transgenic mice treated with vehicle or $\mathrm{LiCl}+\mathrm{CCl}-779$ were analyzed for the presence of foot dragging. In agreement with previous observations (Duarte-Silva et al., 2014; Silva-Fernandes et al., 2014b), at 12 weeks of age this phenotype was established in the CMVMJD135-vehicle animals $\left(p=2 \times 10^{-5}\right)$, while the wt-vehicle animals never presented foot dragging. $\mathrm{LiCl}$ $+\mathrm{CCl}-779$ treatment was not able to improve foot dragging, and actually showed a trend to worsen the phenotype, given by the presence of foot dragging in the wt-treated animals and a higher percentage of $\mathrm{LiCl}$ + CCl-779-treated CMVMJD135 mice with this phenotype at 12 weeks of age (90\% of CMVMJD135-vehicle animals vs. $100 \%$ of CMVMJD135-treated animals showed foot dragging) (Fig. 4D). At 20 weeks of age all the transgenic animals analyzed presented this phenotype $\left(p=2 \times 10^{-5}\right)$.

\section{Beam walk test}

The beam walk test was performed at 20 and 24 weeks of age, when the phenotype of CMVMJD135 mice in this motor test is well established (Silva-Fernandes et al., $2014 b)$. In this particular pre-clinical trial, most of the transgenic animals treated with $\mathrm{LiCl}+\mathrm{CCl}-779$ were unable to perform the task, as shown in Fig. 5. At 20 weeks of age in the $11-\mathrm{mm}$ circle beam, only three (in a total of ten animals) were able to cross the beam (Fig. 5A); these animals performed well in terms of latency to cross the square beam $(12 \mathrm{~mm})$, where seven animals concluded the task, but at this time-point we did not observe statistically significant differences among wt and CMVMJD135-vehicle animals, and no differences for treated animals (Fig. 5B). Later on, at 24 weeks of age, none of the CMVMJD135-treated mice were able to perform the beam walk test, either in the square or 

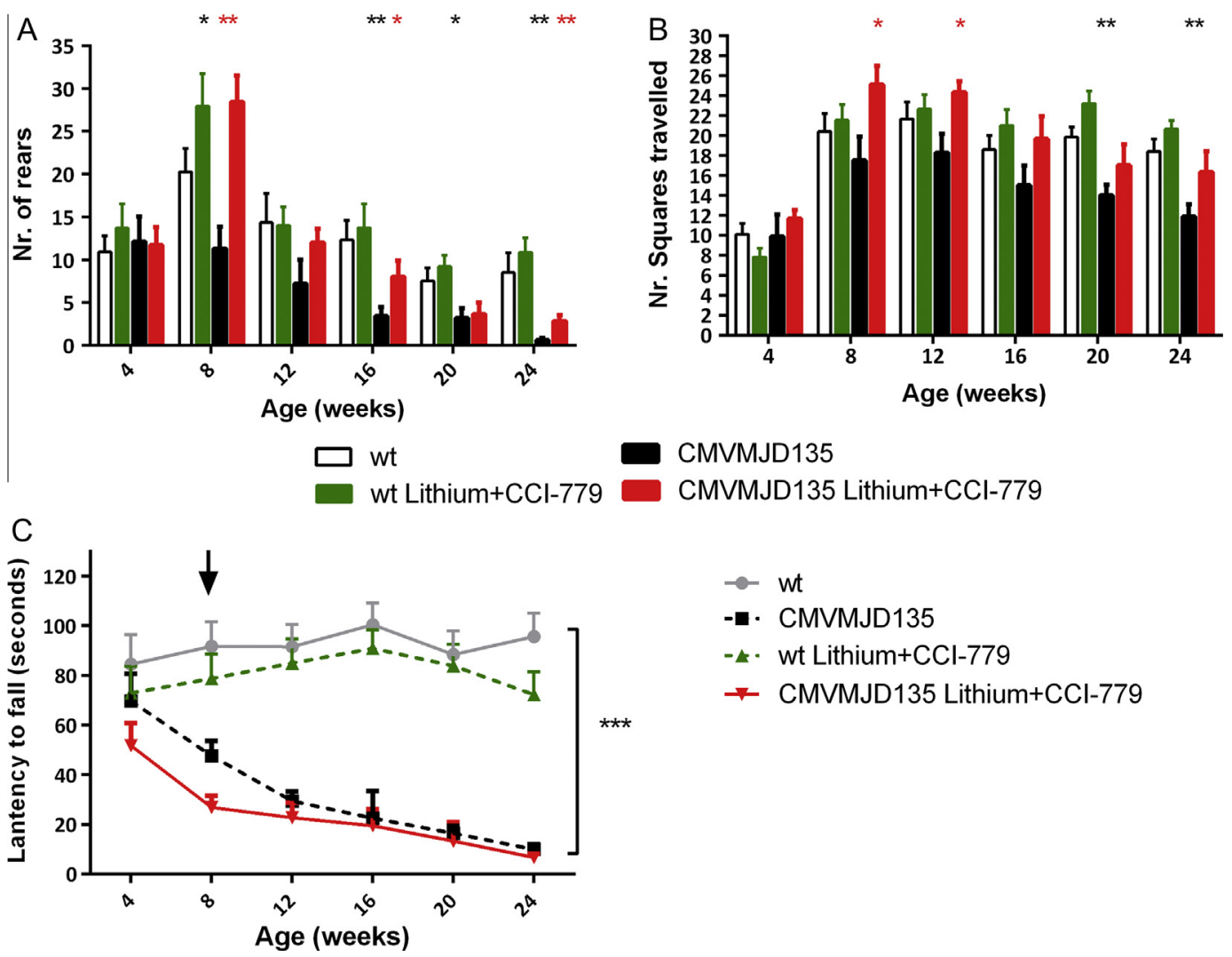

CMVMJD135

CMVMJD135 Lithium+CCl-779

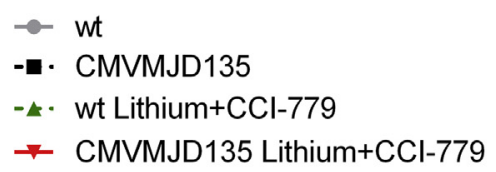

Fig. 3. $\mathrm{LiCl}+\mathrm{CCl}-779$ treatment effect on spontaneous exploratory activity and hindlimb strength. (A) Transgenic animals displayed decreased vertical locomotor activity at 8 weeks of age and subsequent ages, while CMVMJD135-treated mice showed an increased activity at 8,16 and 24 weeks of age ( $n=10-12$ for each group). (B) Transgenic animals traveled less in the arena than wild-type animals at 20 and 24 weeks of age; $\mathrm{LiCl}+\mathrm{CCl}-779$ treatment increased locomotor activity at 8 and 12 weeks of age ( $n=10-12$ for each group). (C) On the hanging wire test all transgenic animals displayed a worse performance in holding the grid with age (from 8 to 24 weeks of age). A maximum time of 2 min was given to each animal and the time that they took to fall was registered ( $n=10-12$ for each group). Symbols represent mean \pm SEM of the different groups. ${ }^{*},{ }^{* *},{ }^{* * *}$ represent $p<0.05,0.01$ or 0.001 , respectively, for genotype factor (two-way ANOVA). Red asterisks represent factor treatment in the analysis (CMVMJD135 mice vs. CMVMJD135-treated mice). Vertical arrow represents the onset of the phenotype. (For interpretation of the references to colour in this figure legend, the reader is referred to the web version of this article.)

the round beams. Taking this into consideration, it is reasonable to consider that $\mathrm{LiCl}+\mathrm{CCl}-779$ treatment had detrimental effects on the transgenic animals, reflected in this balance-dependent task.

\section{Autophagy induction after $\mathrm{LiCl}+\mathrm{CCl}-779$ chronic treatment}

In order to verify autophagy induction after $\mathrm{LiCl}+\mathrm{CCl}-$ 779 combination treatment, we measured in the brainstem of transgenic animals the levels of the autophagy markers LC3 (the classical marker of the autophagosomes; by analyzing the conversion of LC3I to LC3II) (Klionsky et al., 2012), Beclin-1 (a protein involved in the nucleation step of the autophagosome formation) (Itakura et al., 2008) and p62 (a scavenger protein that signals ubiquitylated proteins toward the autophagic machinery that directly interacts with LC3, being itself degraded by autophagy) (Bjorkoy et al., 2005) (Fig. 6A-C, respectively). Similarly to what we observed for $\mathrm{LiCl}$ treatment alone (Duarte-Silva et al., 2014 ), this combined treatment was able to increase the expression of Beclin-1 ( $p=0.007)$, which is associated with autophagy initiation, to increase the LC3II/LC3I ratio, and to decrease the protein levels of the autophagy sub- strate p62 $(p=0.03)$, confirming increased autophagic flux. The degree of autophagy induction was, however, not significantly different between $\mathrm{LiCl}$ and $\mathrm{LiCl}+$ CCl-779 treatments when considering Beclin-1 and p62 autophagy markers (Fig. 6). Due to technical issues, we were not able to perform the Western-blotting analysis for LC3 using the combined and single treatment samples in the same blot membrane. Nevertheless, the assessment using the LC3-II/LC3/I ratio actually suggests the opposite, as we saw an increase of approximately 7-fold for the combined treatment, whereas in our previous study with $\mathrm{LiCl}$ only (Duarte-Silva et al., 2014) we had seen a 1.3-fold increase. So the results with different autophagy markers are not fully concordant regarding the relative extent of activation of autophagy of the combined versus single treatment.

\section{$\mathrm{LiCl}+\mathrm{CCl}-779$ treatment effect on ataxin-3 protein levels and aggregation}

To test the effect of the combinatory drug treatment on steady-state ataxin-3 levels we performed Western-blot analysis. Levels of mutant ataxin-3 in the brainstem of CMVMJD135 showed to be reduced upon $\mathrm{LiCl}+\mathrm{CCl}-$ 779 chronic treatment (Fig. 7A) $(p=0.04)$. Furthermore, 

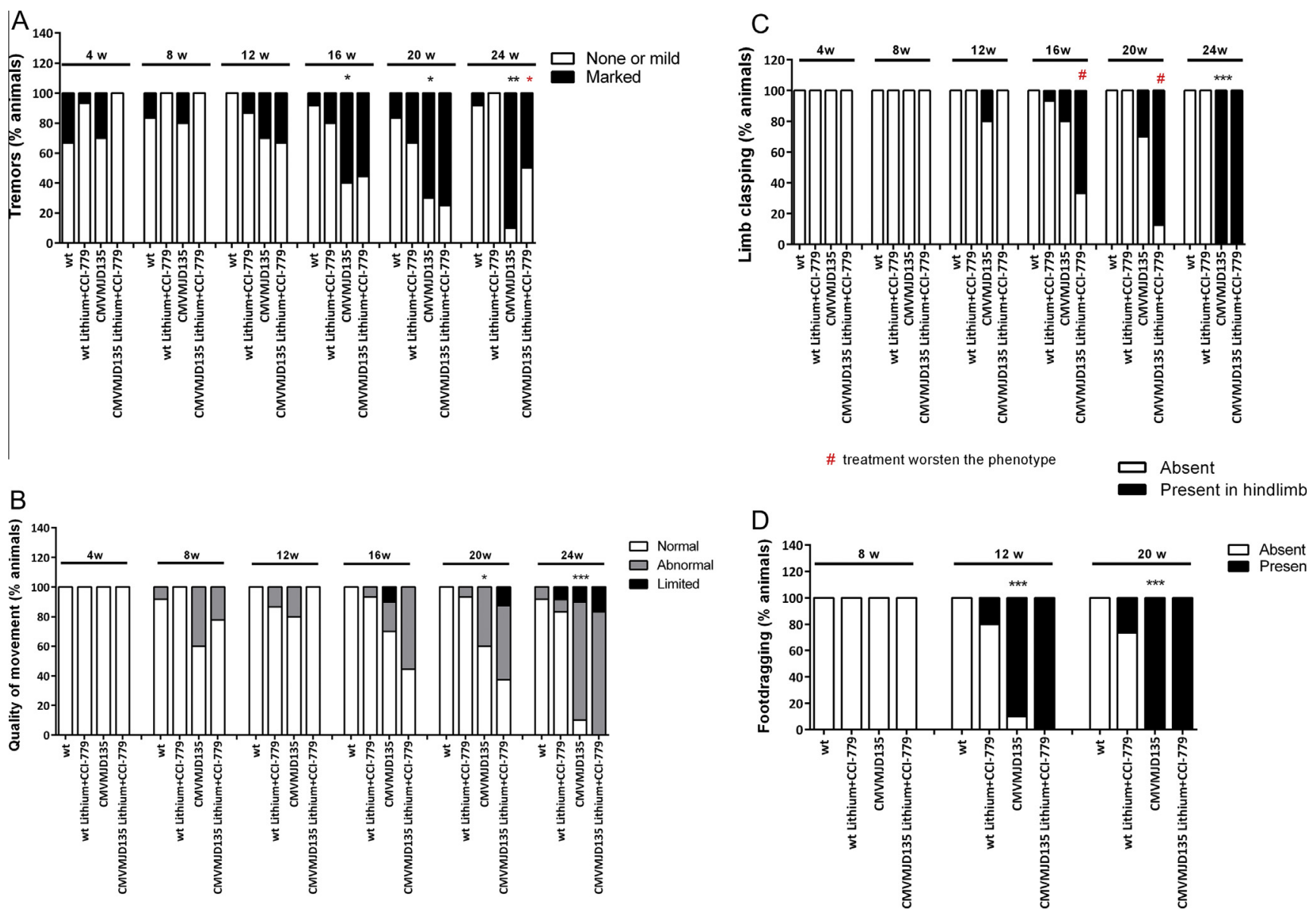

Fig. 4. Effect of $\mathrm{LiCl}+\mathrm{CCl}-779$ treatment on limb clasping, tremors and gait quality. (A) CMVMJD135 mice presented tremors from 16 weeks of age onward. In the last time-point analyzed (24 weeks) $\mathrm{LiCl}+\mathrm{CCl}-779$ treatment slightly improved this phenotype $(n=10-12$ for each group). (B) CMVMJD135 animals had abnormal gait at 20 and 24 weeks of age (qualitative assessment) which was not reverted by LiCl $+\mathrm{CCl}-779(n=10-12$ for each group). (C) Limb clasping was observed in CMVMJD135 mice at 24 weeks of age; $\mathrm{LiCl}+\mathrm{CCl}-779$ treatment anticipated the onset of this symptom, starting in the CMVMJD135-treated group at 16 weeks of age. Red \# represents a worse phenotype observed in the treated group. (D) CMVMJD135 mice drag their feet since 12 weeks of age, which was not improved by LiCl $+\mathrm{CCl}-779$ treatment $(n=10-12$ for each group). Symbols represent mean \pm SEM of the different groups. ${ }^{\star \star \star},{ }^{\star \star},{ }^{\star \star \star}$ represent $p<0.05 ; 0.01$ or 0.001 , respectively (Fisher's exact test).

the number of ATXN3-positive nuclear aggregates was quantified in the pontine nuclei of treated and untreated CMVMJD135 mice at 24 weeks of age (end of the trial). $\mathrm{LiCl}+\mathrm{CCl}-779$ combined treatment significantly decreased the aggregate load in this brain region (Fig. 7B, C) $(p=0.0026)$.

\section{DISCUSSION}

Based on the concept of autophagy induction as a potential therapeutic strategy for neurodegenerative diseases, here we have tested the effect of treatment with a combination of $\mathrm{LiCl}$ and $\mathrm{CCl}-779$ in a mouse model of MJD. It has been demonstrated in another mouse model of this disease that $\mathrm{CCl}-779$ treatment, at the same dosage as used in this work $(20 \mathrm{mg} / \mathrm{kg})$, resulted in an improvement of motor coordination (Menzies et al., 2010). However, the mouse model used had a very mild phenotype, observable only in the Rotarod and non-significantly different from the controls. The CMVMJD135 mouse model allowed us to further test this type of therapeutic strategy, due to its more severe phenotype and broad range of disease features. Furthermore, the combination of an autophagy-inducing compound with an mTOR-dependent and another with an mTOR-independent mode of action was used to test the therapeutic value of simultaneously modifying these complementary pathways.

Our first significant observation was that both wt and transgenic animals treated with $\mathrm{LiCl}+\mathrm{CCl}-779$ had a significant decrease in body weight during the treatment period. The body weight loss in both groups could be due to an exacerbated activation of autophagy in some tissues by the combination of these two drugs (although, unexpectedly, this enhanced induction was not observed with all autophagy markers in the brain), and/or it could reflect some systemic toxicity of this drug combination, also patent in the death of $30 \%$ of the treated animals, even though the doses used in this work for autophagy activation had already been tested in mice and shown not to be toxic, when administered separately (Wood and Morton, 2003; Ravikumar et al., 2004; Duarte-Silva et al., 2014). In fact, the LiCl dosage used here can be considered low ( $\mathrm{LiCl}$ plasma levels of 

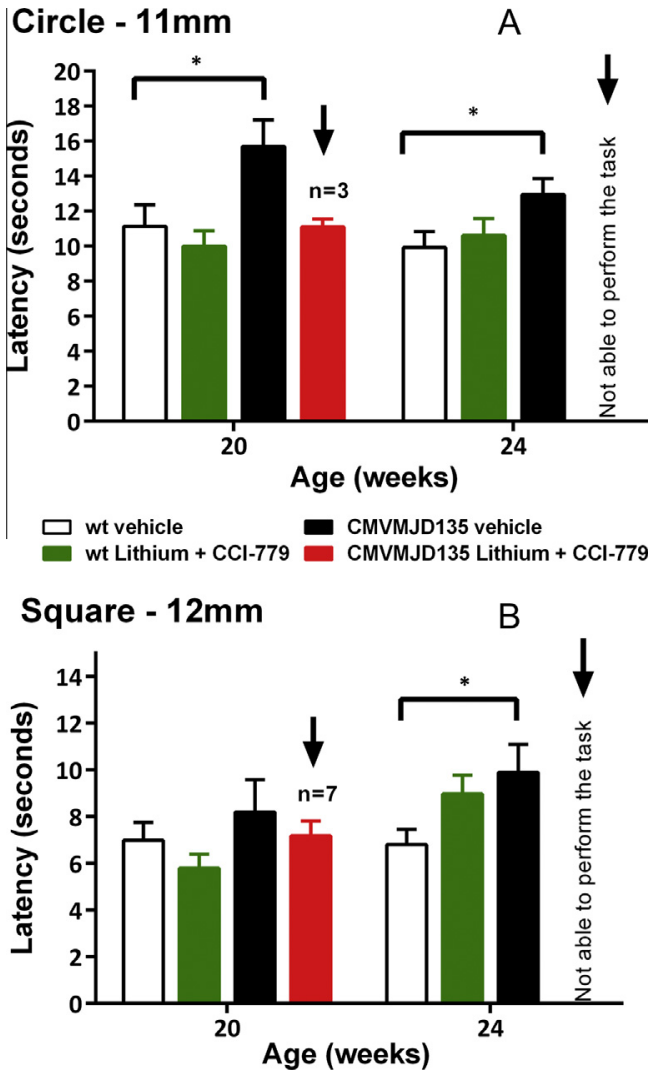

Fig. 5. Effect of $\mathrm{LiCl}+\mathrm{CCl}-779$ treatment on balance and motor coordination. Each bar corresponds to the mean of two consecutive trials in (A) circle and (B) square beams. The time to traverse the beam was videotaped and then measured by the same experimenter. 10-12 animals were used for each condition. CMVMJD135-treated mice showed severe difficulties in performing this task. ${ }^{*}$ represents the $p<0.05$ for genotype factor (two-way ANOVA). Black arrows highlight the low or null number of CMVMJD135-treated mice able to perform the task.
$0.3 \pm 0.09 \mathrm{mmol} / \mathrm{L}$, as estimated previously by us (Duarte-Silva et al., 2014)), being below the therapeutic range used in humans with bipolar disorder (Lin et al., 2006; Duarte-Silva et al., 2014). The toxicity here observed may be related to cellular pathways activated or altered specifically by these two compounds when administered together.

Concerning the neurological phenotype, the effects of the combination therapy were generally not positive. The first manifestation of the disease in the CMVMJD135 model is loss of limb strength, which severely progresses with age (Silva-Fernandes et al., 2014b). Chronic $\mathrm{LiCl}+\mathrm{CCl}-779$ treatment did not improve this muscular strength deficit, in accordance to other treatments previously performed in same model (DuarteSilva et al., 2014; Silva-Fernandes et al., 2014a). Since this phenotype starts early in life and progresses dramatically fast, the treatment regimen that we performed (starting one week before the appearance of the loss of muscular strength) may have been insufficient in terms of duration to rescue this deficit. Furthermore, the combined treatment herein tested appeared to have detrimental effects in treated-CMVMJD135 mice; additionally, this negative impact was also observed in wt animals, which performed worse in this task than vehicle-treated wt mice (although the difference did not reach statistical significance).

Results concerning other neurological parameters also point to very limited therapeutic effects and even some neurotoxicity of the drug combination, namely concerning limb clasping and gait quality, for which the treated transgenic mice presented a more severe phenotype than the vehicle-treated CMVMJD135 animals. Furthermore, the combination of $\mathrm{LiCl}+\mathrm{CCl}-$ 779 had a negative impact on the foot printing pattern of wt animals, since it was possible to detect dragging of
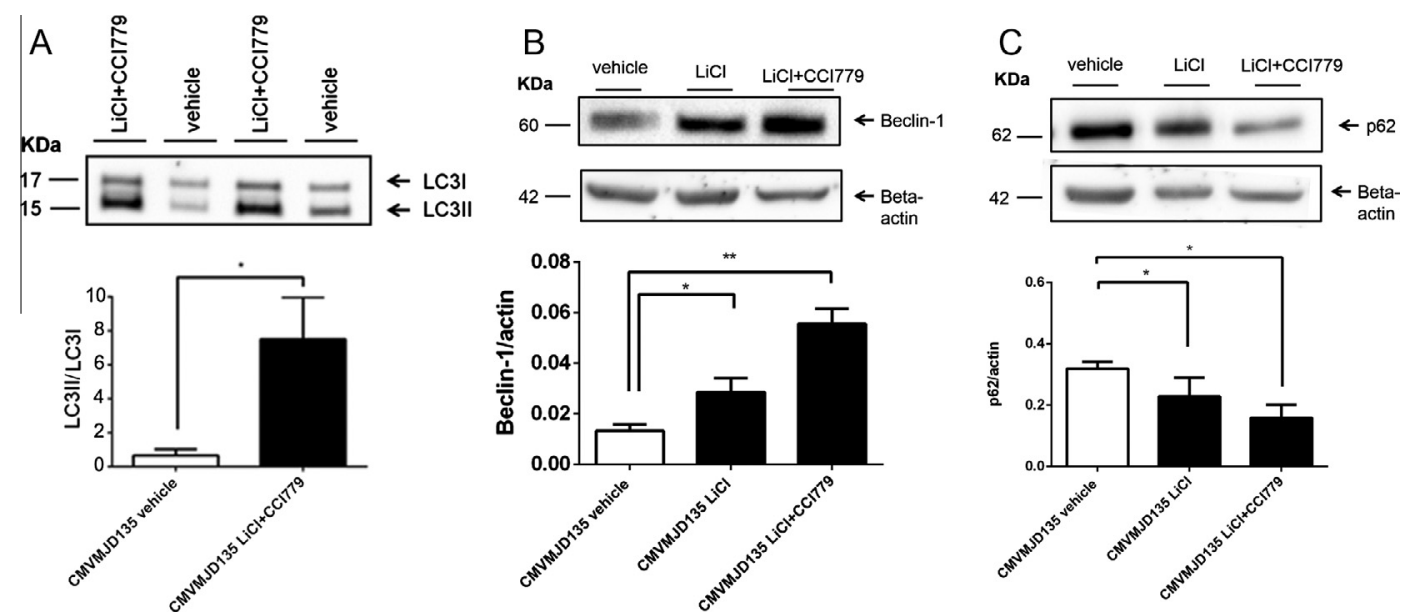

Fig. 6. Autophagy induction by the chronic treatment with $\mathrm{LiCl}+\mathrm{CCl}-779$. (A) Western-blot analysis of LC3 levels in brainstem lysates of transgenic animals injected with vehicle $(n=3)$ or $\mathrm{LiCl}+\mathrm{CCl}-779(n=3)$; (B) Western-blot analysis of beclin-1 in brainstem lysates of transgenic animals injected with vehicle $(n=3)$ or $\mathrm{LiCl}+\mathrm{CCl}-779$, at 10.4 and $20 \mathrm{mg} / \mathrm{kg}$, respectively $(\mathrm{n}=3)$; $(\mathrm{C})$ Western-blot analysis of p62 in brain lysates of transgenic animals injected with vehicle $(n=3)$ or $\mathrm{LiCl}+\mathrm{CCl}-779$ at 10.4 and $20 \mathrm{mg} / \mathrm{kg}$, respectively $(n=3)$; beta-actin was used as loading control. ${ }^{\star},{ }^{\star \star}$, represents $p<0.05$ or 0.01 , respectively (One-Way ANOVA). 


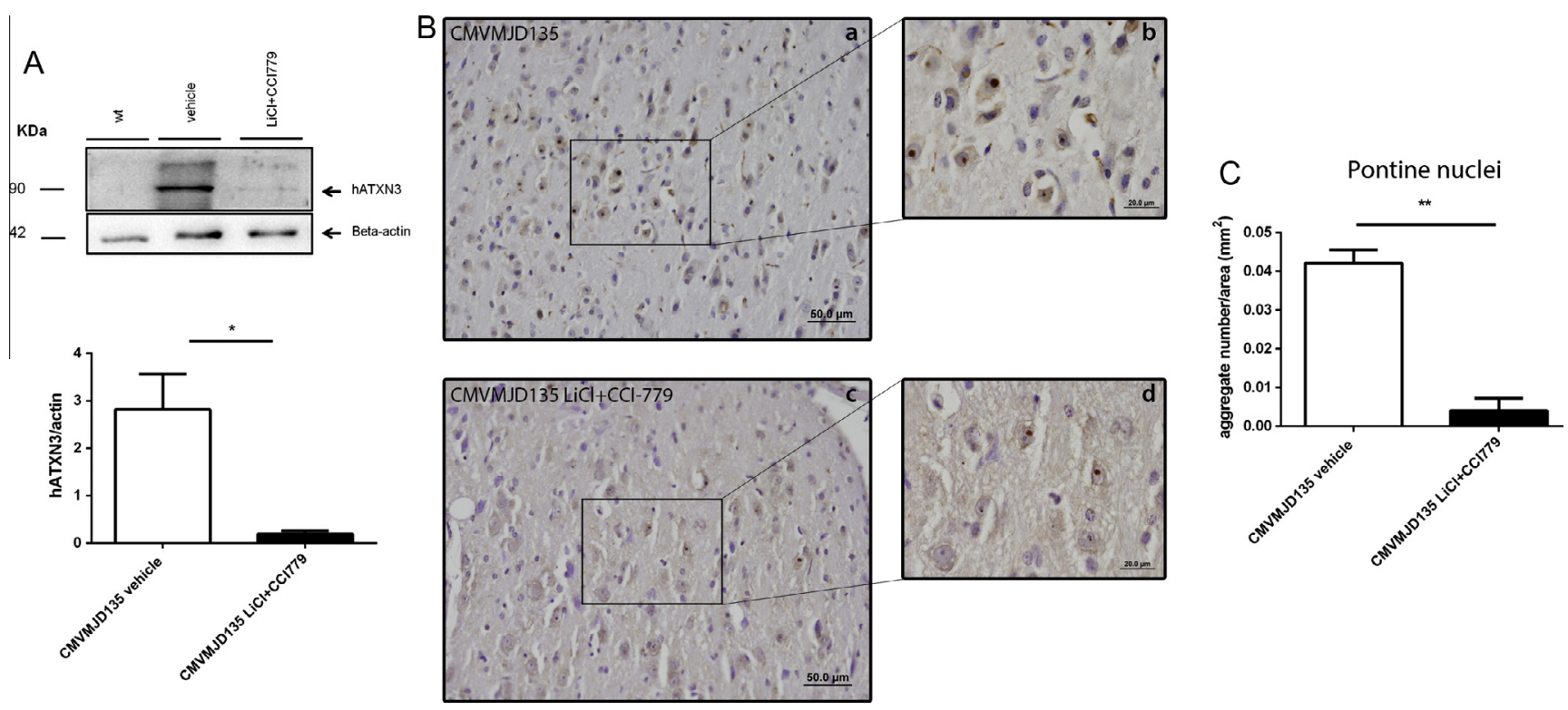

Fig. 7. $\mathrm{LiCl}+\mathrm{CCl}-779$ treatment effect on ataxin-3 levels. (A) Western-blot analysis of ATXN3 in brainstem lysates of transgenic animals injected with vehicle $(n=4)$ or $\mathrm{LiCl}+\mathrm{CCl}-779$, at 10.4 and $20 \mathrm{mg} / \mathrm{kg}$, respectively $(n=4)$; beta-actin was used as loading control. (B) Representative images of anti-ataxin-3 immunohistochemistry in the pontine nuclei of 24-week-old CMVMJD135 untreated (a and b, $n=3,4$ slides per animals) and treated (c and d, $n=3,4$ slides per animal). Scale bar for $a$ and c $50 \mu \mathrm{m}$ and for $\mathrm{b}$ and d $20 \mu \mathrm{m}$. (C) quantification of the number of aggregates in the pontine nuclei. ${ }^{*},{ }^{* *}$ represents the $p<0.05$ or 0.01 , respectively (One-Way ANOVA).

the paws in these animals, which did not occur in vehicletreated wt animals. $\mathrm{LiCl}+\mathrm{CCl}-779$-treated CMVMJD135 animals also showed severe difficulties in the beam walk test; at 24 weeks of age these animals were not able to perform the task in the easier beam (square), while vehicle-treated CMVMJD135 animals at the same age were able to cross this beam (albeit taking longer than wt animals, due to motor deficits associated with the disease). In addition, when difficulty was enhanced by using the round narrower beam, this worsening of the phenotype became detectable at 20 weeks of age. In fact, the neurotoxic effect of the $\mathrm{LiCl}+\mathrm{CCl}-779$ combination treatment is strongly visible in this behavioral test, not allowing the comparative analysis between CMVMJD135 mice (treated vs. vehicle).

Intriguingly, chronic treatment with $\mathrm{LiCl}+\mathrm{CCl}-779$ increased the vertical exploratory behavior in both wt and CMVMJD135 mice. Similar effects, also occurring in wt and CMVMJD135-treated animals, were detected in the spontaneous activity, given by the number of squares traveled in the arena. We had previously shown that $\mathrm{LiCl}$ treatment resulted in increased exploratory behavior in these mice (Duarte-Silva et al., 2014), suggesting that the increase observed in the current study may be due to non-specific effects of this drug, most likely not disease-related.

We also observed a slight improvement of the tremors, which is in agreement with our previous result using $\mathrm{LiCl}$ alone in these mice (Duarte-Silva et al., 2014), suggesting that this improvement might be due to that component of the treatment regimen. The presence of tremors in human patients is a rare event and can be treated with levodopa (Coutinho and Sequeiros, 1981; Ishida et al., 1998; Nandagopal and Moorthy,
2004; Bettencourt et al., 2011), so this improvement may not be very relevant in the disease context.

In summary, these results demonstrate the negative impact of the combination of these two autophagyinducing compounds when administered simultaneously, even in dosages that, upon single compound administration, were safe for mice (Wood and Morton, 2003; Ravikumar et al., 2004; Duarte-Silva et al., 2014). Thus, if any future $\mathrm{LiCl}+\mathrm{CCl}-779$ combination therapy is to be considered for MJD or other polyQ, it would be necessary to adjust the doses of both compounds to avoid toxicity.

\section{CONFLICT OF INTEREST STATEMENT}

The authors declare no conflict of interest.

Acknowledgments-We would like to acknowledge Prof. Pedro Oliveira for statistical analysis support and the animal house caretaker Ms. Celina Barros for technical assistance. This work was supported by Fundação para a Ciência e Tecnologia through the projects [FEDER/FCT, POCI/SAU-MMO/60412/2004], [PTDC/SAU-GMG/64076/2006]. This work was supported by Fundação para a Ciência e Tecnologia through fellowships [SFRH/BD/78388/2011 to S.D.-S., SFRH/BPD/91562/2012 to A. S.-F., SFRH/BD/51059/2010 to A.N.-C., SFRH/BD/51992/2012 to C.S.-C. and SFRH/BPD/79469/2011 to A.T.C.]

\section{REFERENCES}

Anglade P, Vyas S, Javoy-Agid F, Herrero MT, Michel PP, Marquez J, Mouatt-Prigent A, Ruberg M, Hirsch EC, Agid Y (1997) Apoptosis and autophagy in nigral neurons of patients with Parkinson's disease. Histol Histopathol 12:25-31. 
Becher MW, Kotzuk JA, Sharp AH, Davies SW, Bates GP, Price DL, Ross CA (1998) Intranuclear neuronal inclusions in Huntington's disease and dentatorubral and pallidoluysian atrophy: correlation between the density of inclusions and IT15 CAG triplet repeat length. Neurobiol Dis 4:387-397.

Bergmann L, Maute L, Guschmann M (2014) Temsirolimus for advanced renal cell carcinoma. Expert Rev Anticancer Ther 14:9-21.

Bettencourt C, Santos C, Coutinho P, Rizzu P, Vasconcelos J, Kay T, Cymbron T, Raposo M, Heutink P, Lima M (2011) Parkinsonian phenotype in Machado-Joseph disease (MJD/SCA3): a two-case report. BMC Neurol 11:131.

Bjorkoy G, Lamark T, Brech A, Outzen H, Perander M, Overvatn A, Stenmark H, Johansen T (2005) P62/SQSTM1 forms protein aggregates degraded by autophagy and has a protective effect on huntingtin-induced cell death. J Cell Biol 171:603-614.

Boland B, Kumar A, Lee S, Platt FM, Wegiel J, Yu WH, Nixon RA (2008) Autophagy induction and autophagosome clearance in neurons: relationship to autophagic pathology in Alzheimer's disease. J Neurosci 28:6926-6937.

Brenner S (1974) The genetics of Caenorhabditis elegans. Genetics 77:71-94.

Cataldo AM, Hamilton DJ, Barnett JL, Paskevich PA, Nixon RA (1996) Properties of the endosomal-lysosomal system in the human central nervous system: disturbances mark most neurons in populations at risk to degenerate in Alzheimer's disease. J Neurosci 16:186-199.

Chiu CT, Chuang DM (2010) Molecular actions and therapeutic potential of lithium in preclinical and clinical studies of CNS disorders. Pharmacol Ther 128:281-304.

Coutinho P, Sequeiros J (1981) Clinical, genetic and pathological aspects of Machado-Joseph disease. J Genet Hum 29:203-209.

Duarte-Silva S, Neves-Carvalho A, Soares-Cunha C, Teixeira-Castro A, Oliveira P, Silva-Fernandes A, Maciel P (2014) Lithium chloride therapy fails to improve motor function in a transgenic mouse model of Machado-Joseph disease. Cerebellum 13:713-727.

Duenas AM, Goold R, Giunti P (2006) Molecular pathogenesis of spinocerebellar ataxias. Brain 129:1357-1370.

Gidalevitz T, Ben-Zvi A, Ho KH, Brignull HR, Morimoto RI (2006) Progressive disruption of cellular protein folding in models of polyglutamine diseases. Science 311:1471-1474.

Gusella JF, MacDonald ME (2000) Molecular genetics: unmasking polyglutamine triggers in neurodegenerative disease. Nat Rev Neurosci 1:109-115.

Ishida C, Sakajiri K, Yoshikawa H, Sakashita Y, Okino S, Yamaguchi K, Takamori M (1998) Lower limb tremor in Machado-Joseph disease. Neurology 51:1225-1226.

Itakura E, Kishi C, Inoue K, Mizushima N (2008) Beclin 1 forms two distinct phosphatidylinositol 3-kinase complexes with mammalian Atg14 and UVRAG. Mol Biol Cell 19:5360-5372.

Kawaguchi $\mathrm{Y}$, Okamoto $\mathrm{T}$, Taniwaki M, Aizawa M, Inoue M, Katayama S, Kawakami H, Nakamura S, Nishimura M, Akiguchi I, et al. (1994) CAG expansions in a novel gene for MachadoJoseph disease at chromosome 14q32.1. Nat Genet 8:221-228.

Kelekar A (2005) Autophagy. Ann NY Acad Sci 1066:259-271.

Klionsky DJ, Abdalla FC, Abeliovich H, Abraham RT, AcevedoArozena A, Adeli K, Agholme L, Agnello M, Agostinis P, AguirreGhiso JA, Ahn HJ, Ait-Mohamed O, Ait-Si-Ali S, Akematsu T, Akira S, Al-Younes HM, Al-Zeer MA, Albert ML, Albin RL, AlegreAbarrategui J, Aleo MF, Alirezaei M, Almasan A, Almonte-Becerril $\mathrm{M}$, Amano A, Amaravadi R, Amarnath S, Amer AO, AndrieuAbadie N, Anantharam V, Ann DK, Anoopkumar-Dukie S, Aoki H, Apostolova N, Arancia G, Aris JP, Asanuma K, Asare NY, Ashida $\mathrm{H}$, Askanas V, Askew DS, Auberger P, Baba M, Backues SK, Baehrecke EH, Bahr BA, Bai XY, Bailly Y, Baiocchi R, Baldini G, Balduini W, Ballabio A, Bamber BA, Bampton ET, Banhegyi G, Bartholomew CR, Bassham DC, Bast Jr RC, Batoko H, Bay BH, Beau I, Bechet DM, Begley TJ, Behl C, Behrends C, Bekri S, Bellaire B, Bendall LJ, Benetti L, Berliocchi L, Bernardi $H$, Bernassola F, Besteiro S, Bhatia-Kissova I, Bi X, BiardPiechaczyk M, Blum JS, Boise LH, Bonaldo P, Boone DL,
Bornhauser BC, Bortoluci KR, Bossis I, Bost F, Bourquin JP, Boya P, Boyer-Guittaut M, Bozhkov PV, Brady NR, Brancolini C, Brech A, Brenman JE, Brennand A, Bresnick EH, Brest P, Bridges D, Bristol ML, Brookes PS, Brown EJ, Brumell JH, Brunetti-Pierri N, Brunk UT, Bulman DE, Bultman SJ, Bultynck G, Burbulla LF, Bursch W, Butchar JP, Buzgariu W, Bydlowski SP, Cadwell K, Cahova M, Cai D, Cai J, Cai Q, Calabretta B, Calvo-Garrido J, Camougrand N, Campanella M, Campos-Salinas J, Candi E, Cao L, Caplan AB, Carding SR, Cardoso SM, Carew JS, Carlin CR, Carmignac V, Carneiro LA, Carra S, Caruso RA, Casari G, Casas C, Castino R, Cebollero E, Cecconi F, Celli J, Chaachouay H, Chae HJ, Chai CY, Chan DC, Chan EY, Chang RC, Che CM, Chen CC, Chen GC, Chen GQ, Chen M, Chen Q, Chen SS, Chen W, Chen X, Chen X, Chen X, Chen YG, Chen Y, Chen Y, Chen YJ, Chen Z, Cheng A, Cheng $\mathrm{CH}$, Cheng $\mathrm{Y}$, Cheong $\mathrm{H}$, Cheong $\mathrm{JH}$, Cherry S, Chess-Williams R, Cheung ZH, Chevet E, Chiang $\mathrm{HL}$, Chiarelli R, Chiba T, Chin LS, Chiou SH, Chisari FV, Cho CH, Cho DH, Choi AM, Choi D, Choi KS, Choi ME, Chouaib S, Choubey D, Choubey V, Chu CT, Chuang TH, Chueh SH, Chun T, Chwae YJ, Chye ML, Ciarcia R, Ciriolo MR, Clague MJ, Clark RS, Clarke PG, Clarke R, Codogno P, Coller HA, Colombo MI, Comincini S, Condello M, Condorelli F, Cookson MR, Coombs $\mathrm{GH}$, Coppens I, Corbalan R, Cossart P, Costelli P, Costes S, Coto-Montes A, Couve E, Coxon FP, Cregg JM, Crespo JL, Cronje MJ, Cuervo AM, Cullen JJ, Czaja MJ, D'Amelio M, Darfeuille-Michaud A, Davids LM, Davies FE, De Felici M, de Groot JF, de Haan CA, De Martino L, De Milito A, De Tata V, Debnath J, Degterev A, Dehay B, Delbridge LM, Demarchi F, Deng YZ, Dengjel J, Dent P, Denton D, Deretic V, Desai SD, Devenish RJ, Di Gioacchino M, Di Paolo G, Di Pietro C, DiazAraya G, Diaz-Laviada I, Diaz-Meco MT, Diaz-Nido J, Dikic I, Dinesh-Kumar SP, Ding WX, Distelhorst CW, Diwan A, DjavaheriMergny M, Dokudovskaya S, Dong Z, Dorsey FC, Dosenko V, Dowling JJ, Doxsey S, Dreux M, Drew ME, Duan Q, Duchosal MA, Duff K, Dugail I, Durbeej M, Duszenko M, Edelstein CL, Edinger AL, Egea G, Eichinger L, Eissa NT, Ekmekcioglu S, ElDeiry WS, Elazar Z, Elgendy M, Ellerby LM, Eng KE, Engelbrecht AM, Engelender S, Erenpreisa J, Escalante R, Esclatine A, Eskelinen EL, Espert L, Espina V, Fan H, Fan J, Fan QW, Fan Z, Fang S, Fang $\mathrm{Y}$, Fanto M, Fanzani A, Farkas T, Farre JC, Faure M, Fechheimer M, Feng CG, Feng J, Feng Q, Feng Y, Fesus L, Feuer R, Figueiredo-Pereira ME, Fimia GM, Fingar DC, Finkbeiner S, Finkel T, Finley KD, Fiorito F, Fisher EA, Fisher $\mathrm{PB}$, Flajolet M, Florez-McClure ML, Florio S, Fon EA, Fornai F, Fortunato F, Fotedar R, Fowler DH, Fox HS, Franco R, Frankel LB, Fransen M, Fuentes JM, Fueyo J, Fujii J, Fujisaki K, Fujita E, Fukuda M, Furukawa RH, Gaestel M, Gailly P, Gajewska M, Galliot B, Galy V, Ganesh S, Ganetzky B, Ganley IG, Gao FB, Gao GF, Gao J, Garcia L, Garcia-Manero G, Garcia-Marcos M, Garmyn M, Gartel AL, Gatti E, Gautel M, Gawriluk TR, Gegg ME, Geng J, Germain M, Gestwicki JE, Gewirtz DA, Ghavami S, Ghosh P, Giammarioli AM, Giatromanolaki AN, Gibson SB, Gilkerson RW, Ginger ML, Ginsberg HN, Golab J, Goligorsky MS, Golstein P, Gomez-Manzano C, Goncu E, Gongora C, Gonzalez CD, Gonzalez R, Gonzalez-Estevez C, Gonzalez-Polo RA, Gonzalez-Rey E, Gorbunov NV, Gorski S, Goruppi S, Gottlieb RA, Gozuacik D, Granato GE, Grant GD, Green KN, Gregorc A, Gros F, Grose C, Grunt TW, Gual P, Guan JL, Guan KL, Guichard SM, Gukovskaya AS, Gukovsky I, Gunst J, Gustafsson AB, Halayko AJ, Hale AN, Halonen SK, Hamasaki M, Han F, Han T, Hancock MK, Hansen M, Harada H, Harada M, Hardt SE, Harper JW, Harris AL, Harris J, Harris SD, Hashimoto M, Haspel JA, Hayashi S, Hazelhurst LA, He C, He YW, Hebert MJ, Heidenreich KA, Helfrich MH, Helgason GV, Henske EP, Herman B, Herman PK, Hetz C, Hilfiker S, Hill JA, Hocking LJ, Hofman P, Hofmann TG, Hohfeld J, Holyoake TL, Hong MH, Hood DA, Hotamisligil GS, Houwerzijl EJ, Hoyer-Hansen M, Hu B, Hu CA, Hu HM, Hua Y, Huang C, Huang J, Huang S, Huang WP, Huber TB, Huh WK, Hung TH, Hupp TR, Hur GM, Hurley JB, Hussain SN, Hussey PJ, Hwang JJ, Hwang S, Ichihara A, Ilkhanizadeh S, Inoki K, Into T, lovane V, lovanna JL, Ip NY, Isaka 
$\mathrm{Y}$, Ishida $\mathrm{H}$, Isidoro $\mathrm{C}$, Isobe $\mathrm{K}$, Iwasaki A, Izquierdo $\mathrm{M}$, Izumi $\mathrm{Y}$, Jaakkola PM, Jaattela M, Jackson GR, Jackson WT, Janji B, Jendrach $M$, Jeon $J H$, Jeung $E B$, Jiang $H$, Jiang $H$, Jiang JX, Jiang $M$, Jiang $Q$, Jiang $X$, Jiang $X$, Jimenez $A$, Jin $M$, Jin $S$, Joe CO, Johansen $T$, Johnson DE, Johnson GV, Jones NL, Joseph B, Joseph SK, Joubert AM, Juhasz G, Juillerat-Jeanneret L, Jung $\mathrm{CH}$, Jung YK, Kaarniranta K, Kaasik A, Kabuta T, Kadowaki M, Kagedal K, Kamada Y, Kaminskyy VO, Kampinga HH, Kanamori $\mathrm{H}$, Kang C, Kang KB, Kang KI, Kang R, Kang YA, Kanki T, Kanneganti TD, Kanno H, Kanthasamy AG, Kanthasamy A, Karantza V, Kaushal GP, Kaushik S, Kawazoe Y, Ke PY, Kehrl JH, Kelekar A, Kerkhoff C, Kessel DH, Khalil H, Kiel JA, Kiger AA, Kihara A, Kim DR, Kim DH, Kim DH, Kim EK, Kim HR, Kim JS, Kim JH, Kim JC, Kim JK, Kim PK, Kim SW, Kim YS, Kim Y, Kimchi A, Kimmelman AC, King JS, Kinsella TJ, Kirkin V, Kirshenbaum LA, Kitamoto K, Kitazato K, Klein L, Klimecki WT, Klucken J, Knecht E, Ko BC, Koch JC, Koga H, Koh JY, Koh YH, Koike M, Komatsu M, Kominami E, Kong HJ, Kong WJ, Korolchuk VI, Kotake Y, Koukourakis MI, Kouri Flores JB, Kovacs AL, Kraft C, Krainc D, Kramer H, Kretz-Remy C, Krichevsky AM, Kroemer G, Kruger R, Krut O, Ktistakis NT, Kuan CY, Kucharczyk R, Kumar A, Kumar R, Kumar S, Kundu M, Kung HJ, Kurz T, Kwon HJ, La Spada AR, Lafont F, Lamark T, Landry J, Lane JD, Lapaquette P, Laporte JF, Laszlo L, Lavandero S, Lavoie JN, Layfield R, Lazo PA, Le W, Le Cam L, Ledbetter DJ, Lee AJ, Lee BW, Lee GM, Lee J, Lee JH, Lee M, Lee MS, Lee SH, Leeuwenburgh C, Legembre $P$, Legouis $R$, Lehmann M, Lei HY, Lei QY, Leib DA, Leiro J, Lemasters JJ, Lemoine A, Lesniak MS, Lev D, Levenson VV, Levine B, Levy E, Li F, Li JL, Li L, Li S, Li W, Li XJ, Li YB, Li YP, Liang C, Liang Q, Liao YF, Liberski PP, Lieberman A, Lim HJ, Lim KL, Lim K, Lin CF, Lin FC, Lin J, Lin JD, Lin K, Lin WW, Lin WC, Lin $Y L$, Linden R, Lingor P, Lippincott-Schwartz J, Lisanti MP, Liton PB, Liu B, Liu CF, Liu K, Liu L, Liu QA, Liu W, Liu YC, Liu Y, Lockshin RA, Lok CN, Lonial S, Loos B, Lopez-Berestein G, Lopez-Otin C, Lossi L, Lotze MT, Low P, Lu B, Lu B, Lu B, Lu Z, Luciano F, Lukacs NW, Lund AH, Lynch-Day MA, Ma Y, Macian F, MacKeigan JP, Macleod KF, Madeo F, Maiuri L, Maiuri MC, Malagoli D, Malicdan MC, Malorni W, Man N, Mandelkow EM, Manon S, Manov I, Mao K, Mao X, Mao Z, Marambaud P, Marazziti D, Marcel YL, Marchbank K, Marchetti P, Marciniak SJ, Marcondes M, Mardi M, Marfe G, Marino G, Markaki M, Marten MR, Martin SJ, Martinand-Mari C, Martinet W, Martinez-Vicente M, Masini M, Matarrese P, Matsuo S, Matteoni R, Mayer A, Mazure NM, McConkey DJ, McConnell MJ, McDermott C, McDonald C, Mclnerney GM, McKenna SL, McLaughlin B, McLean PJ, McMaster CR, McQuibban GA, Meijer AJ, Meisler MH, Melendez A, Melia TJ, Melino G, Mena MA, Menendez JA, Menna-Barreto RF, Menon MB, Menzies FM, Mercer CA, Merighi A, Merry DE, Meschini S, Meyer CG, Meyer TF, Miao CY, Miao JY, Michels PA, Michiels C, Mijaljica D, Milojkovic A, Minucci S, Miracco C, Miranti CK, Mitroulis I, Miyazawa K, Mizushima N, Mograbi B, Mohseni S, Molero X, Mollereau B, Mollinedo F, Momoi T, Monastyrska I, Monick MM, Monteiro MJ, Moore MN, Mora R, Moreau K, Moreira PI, Moriyasu Y, Moscat J, Mostowy S, Mottram JC, Motyl T, Moussa CE, Muller S, Muller S, Munger K, Munz C, Murphy LO, Murphy ME, Musaro A, Mysorekar I, Nagata E, Nagata K, Nahimana A, Nair U, Nakagawa T, Nakahira K, Nakano H, Nakatogawa H, Nanjundan M, Naqvi NI, Narendra DP, Narita M, Navarro M, Nawrocki ST, Nazarko TY, Nemchenko A, Netea MG, Neufeld TP, Ney PA, Nezis IP, Nguyen HP, Nie D, Nishino I, Nislow C, Nixon RA, Noda T, Noegel AA, Nogalska A, Noguchi S, Notterpek L, Novak I, Nozaki T, Nukina N, Nurnberger T, Nyfeler B, Obara K, Oberley TD, Oddo S, Ogawa M, Ohashi T, Okamoto K, Oleinick NL, Oliver FJ, Olsen LJ, Olsson S, Opota O, Osborne TF, Ostrander GK, Otsu K, Ou JH, Ouimet M, Overholtzer M, Ozpolat B, Paganetti P, Pagnini U, Pallet N, Palmer GE, Palumbo C, Pan T, Panaretakis T, Pandey UB, Papackova Z, Papassideri I, Paris I, Park J, Park OK, Parys JB, Parzych KR, Patschan S, Patterson C, Pattingre S, Pawelek JM, Peng J, Perlmutter DH, Perrotta I, Perry G, Pervaiz S, Peter M, Peters GJ, Petersen M, Petrovski G, Phang JM, Piacentini M,
Pierre P, Pierrefite-Carle V, Pierron G, Pinkas-Kramarski R, Piras A, Piri N, Platanias LC, Poggeler S, Poirot M, Poletti A, Pous C, Pozuelo-Rubio M, Praetorius-lbba M, Prasad A, Prescott M, Priault M, Produit-Zengaffinen N, Progulske-Fox A, ProikasCezanne T, Przedborski S, Przyklenk K, Puertollano R, Puyal J, Qian SB, Qin L, Qin ZH, Quaggin SE, Raben N, Rabinowich H, Rabkin SW, Rahman I, Rami A, Ramm G, Randall G, Randow F, Rao VA, Rathmell JC, Ravikumar B, Ray SK, Reed BH, Reed JC, Reggiori F, Regnier-Vigouroux A, Reichert AS, Reiners Jr JJ, Reiter RJ, Ren J, Revuelta JL, Rhodes CJ, Ritis K, Rizzo E, Robbins J, Roberge M, Roca H, Roccheri MC, Rocchi S, Rodemann HP, Rodriguez de Cordoba S, Rohrer B, Roninson IB, Rosen K, Rost-Roszkowska MM, Rouis M, Rouschop KM, Rovetta F, Rubin BP, Rubinsztein DC, Ruckdeschel K, Rucker 3rd EB, Rudich A, Rudolf E, Ruiz-Opazo N, Russo R, Rusten TE, Ryan KM, Ryter SW, Sabatini DM, Sadoshima J, Saha T, Saitoh T, Sakagami H, Sakai Y, Salekdeh GH, Salomoni P, Salvaterra PM, Salvesen G, Salvioli R, Sanchez AM, Sanchez-Alcazar JA, Sanchez-Prieto R, Sandri M, Sankar U, Sansanwal P, Santambrogio L, Saran S, Sarkar S, Sarwal M, Sasakawa C, Sasnauskiene A, Sass M, Sato K, Sato M, Schapira AH, Scharl M, Schatzl HM, Scheper W, Schiaffino S, Schneider C, Schneider ME, Schneider-Stock R, Schoenlein PV, Schorderet DF, Schuller C, Schwartz GK, Scorrano L, Sealy L, Seglen PO, Segura-Aguilar J, Seiliez I, Seleverstov O, Sell C, Seo JB, Separovic D, Setaluri V, Setoguchi T, Settembre C, Shacka JJ, Shanmugam M, Shapiro IM, Shaulian E, Shaw RJ, Shelhamer JH, Shen HM, Shen WC, Sheng ZH, Shi Y, Shibuya K, Shidoji Y, Shieh JJ, Shih CM, Shimada Y, Shimizu S, Shintani T, Shirihai OS, Shore GC, Sibirny AA, Sidhu SB, Sikorska B, Silva-Zacarin EC, Simmons A, Simon AK, Simon HU, Simone C, Simonsen A, Sinclair DA, Singh R, Sinha D, Sinicrope FA, Sirko A, Siu PM, Sivridis E, Skop V, Skulachev VP, Slack RS, Smaili SS, Smith DR, Soengas MS, Soldati T, Song X, Sood AK, Soong TW, Sotgia F, Spector SA, Spies CD, Springer W, Srinivasula SM, Stefanis L, Steffan JS, Stendel R, Stenmark H, Stephanou A, Stern ST, Sternberg C, Stork B, Stralfors P, Subauste CS, Sui X, Sulzer D, Sun J, Sun SY, Sun ZJ, Sung JJ, Suzuki K, Suzuki T, Swanson MS, Swanton C, Sweeney ST, Sy LK, Szabadkai G, Tabas I, Taegtmeyer H, Tafani M, Takacs-Vellai K, Takano Y, Takegawa K, Takemura G, Takeshita F, Talbot NJ, Tan KS, Tanaka K, Tanaka K, Tang D, Tang D, Tanida I, Tannous BA, Tavernarakis N, Taylor GS, Taylor GA, Taylor JP, Terada LS, Terman A, Tettamanti G, Thevissen K, Thompson CB, Thorburn A, Thumm M, Tian F, Tian Y, TocchiniValentini G, Tolkovsky AM, Tomino Y, Tonges L, Tooze SA, Tournier C, Tower J, Towns R, Trajkovic V, Travassos LH, Tsai TF, Tschan MP, Tsubata T, Tsung A, Turk B, Turner LS, Tyagi SC, Uchiyama $Y$, Ueno T, Umekawa M, Umemiya-Shirafuji R, Unni VK, Vaccaro MI, Valente EM, Van den Berghe G, van der Klei IJ, van Doorn W, van Dyk LF, van Egmond M, van Grunsven LA, Vandenabeele P, Vandenberghe WP, Vanhorebeek I, Vaquero EC, Velasco G, Vellai T, Vicencio JM, Vierstra RD, Vila M, Vindis C, Viola G, Viscomi MT, Voitsekhovskaja OV, von Haefen C, Votruba M, Wada K, Wade-Martins R, Walker CL, Walsh CM, Walter J, Wan XB, Wang A, Wang C, Wang D, Wang F, Wang F, Wang G, Wang H, Wang HG, Wang HD, Wang J, Wang $\mathrm{K}$, Wang $\mathrm{M}$, Wang RC, Wang $X$, Wang $X$, Wang YJ, Wang Y, Wang Z, Wang ZC, Wang Z, Wansink DG, Ward DM, Watada H, Waters SL, Webster P, Wei L, Weihl CC, Weiss WA, Welford SM, Wen LP, Whitehouse CA, Whitton JL, Whitworth AJ, Wileman $T$, Wiley JW, Wilkinson $S$, Willbold $D$, Williams RL, Williamson PR, Wouters BG, Wu C, Wu DC, Wu WK, Wyttenbach A, Xavier RJ, Xi Z, Xia P, Xiao G, Xie Z, Xie Z, Xu DZ, Xu J, Xu L, Xu X, Yamamoto A, Yamamoto A, Yamashina S, Yamashita M, Yan X, Yanagida M, Yang DS, Yang E, Yang JM, Yang SY, Yang W, Yang WY, Yang Z, Yao MC, Yao TP, Yeganeh B, Yen WL, Yin JJ, Yin XM, Yoo OJ, Yoon G, Yoon SY, Yorimitsu T, Yoshikawa Y, Yoshimori T, Yoshimoto K, You HJ, Youle RJ, Younes A, Yu L, Yu L, Yu SW, Yu WH, Yuan ZM, Yue Z, Yun CH, Yuzaki M, Zabirnyk $\mathrm{O}$, Silva-Zacarin E, Zacks D, Zacksenhaus E, Zaffaroni N, Zakeri Z, Zeh 3rd HJ, Zeitlin SO, Zhang H, Zhang HL, Zhang J, Zhang 
JP, Zhang L, Zhang L, Zhang MY, Zhang XD, Zhao M, Zhao YF, Zhao Y, Zhao ZJ, Zheng X, Zhivotovsky B, Zhong Q, Zhou CZ, Zhu C, Zhu WG, Zhu XF, Zhu X, Zhu Y, Zoladek T, Zong WX, Zorzano A, Zschocke J, Zuckerbraun B (2012) Guidelines for the use and interpretation of assays for monitoring autophagy. Autophagy 8:445-544.

Kwitkowski VE, Prowell TM, Ibrahim A, Farrell AT, Justice R, Mitchell SS, Sridhara R, Pazdur R (2010) FDA approval summary: temsirolimus as treatment for advanced renal cell carcinoma. Oncologist 15:428-435.

Levine B, Klionsky DJ (2004) Development by self-digestion: molecular mechanisms and biological functions of autophagy. Dev Cell 6:463-477.

Lin D, Mok H, Yatham LN (2006) Polytherapy in bipolar disorder. CNS Drugs 20:29-42.

Maciel P, Gaspar C, DeStefano AL, Silveira I, Coutinho P, Radvany J, Dawson DM, Sudarsky L, Guimaraes J, Loureiro JE, et al. (1995) Correlation between CAG repeat length and clinical features in Machado-Joseph disease. Am J Hum Genet 57:54-61.

Martinez-Vicente M, Talloczy Z, Wong E, Tang G, Koga H, Kaushik S, de Vries R, Arias E, Harris S, Sulzer D, Cuervo AM (2010) Cargo recognition failure is responsible for inefficient autophagy in Huntington's disease. Nat Neurosci 13:567-576.

Menzies FM, Huebener J, Renna M, Bonin M, Riess O, Rubinsztein DC (2010) Autophagy induction reduces mutant ataxin-3 levels and toxicity in a mouse model of spinocerebellar ataxia type 3 . Brain 133:93-104.

Moreira PI, Siedlak SL, Wang X, Santos MS, Oliveira CR, Tabaton M, Nunomura A, Szweda LI, Aliev G, Smith MA, Zhu X, Perry G (2007) Autophagocytosis of mitochondria is prominent in Alzheimer disease ( $\mathrm{vol} 66, \mathrm{pg} 525,2007$ ). J Neuropath Exp Neur 66. 674-674.

Nandagopal R, Moorthy SG (2004) Dramatic levodopa responsiveness of dystonia in a sporadic case of spinocerebellar ataxia type 3. Postgrad Med J 80:363-365.

Nascimento-Ferreira I, Santos-Ferreira T, Sousa-Ferreira L, Auregan G, Onofre I, Alves S, Dufour N, Colomer Gould VF, Koeppen A, Deglon N, Pereira de Almeida L (2011) Overexpression of the autophagic beclin-1 protein clears mutant ataxin-3 and alleviates Machado-Joseph disease. Brain 134:1400-1415.

Nicklas W, Baneux P, Boot R, Decelle T, Deeny AA, Fumanelli M, Illgen-Wilcke B, Felasa (2002) Recommendations for the health monitoring of rodent and rabbit colonies in breeding and experimental units. Lab Anim 36:20-42.

Nixon RA, Wegiel J, Kumar A, Yu WH, Peterhoff C, Cataldo A, Cuervo AM (2005) Extensive involvement of autophagy in Alzheimer disease: an immuno-electron microscopy study. J Neuropathol Exp Neurol 64:113-122.

Paulson HL (1999) Protein fate in neurodegenerative proteinopathies: polyglutamine diseases join the (mis)fold. Am J Hum Genet 64:339-345.

Ravikumar B, Duden R, Rubinsztein DC (2002) Aggregate-prone proteins with polyglutamine and polyalanine expansions are degraded by autophagy. Hum Mol Genet 11:1107-1117.

Ravikumar B, Vacher C, Berger Z, Davies JE, Luo S, Oroz LG, Scaravilli F, Easton DF, Duden R, O'Kane CJ, Rubinsztein DC (2004) Inhibition of mTOR induces autophagy and reduces toxicity of polyglutamine expansions in fly and mouse models of Huntington disease. Nat Genet 36:585-595.

Rubinsztein DC, Gestwicki JE, Murphy LO, Klionsky DJ (2007) Potential therapeutic applications of autophagy. Nat Rev Drug Disc 6:304-312.
Sarkar S, Floto RA, Berger Z, Imarisio S, Cordenier A, Pasco M, Cook LJ, Rubinsztein DC (2005) Lithium induces autophagy by inhibiting inositol monophosphatase. J Cell Biol 170:1101-1111.

Sarkar S, Ravikumar B, Floto RA, Rubinsztein DC (2009) Rapamycin and mTOR-independent autophagy inducers ameliorate toxicity of polyglutamine-expanded huntingtin and related proteinopathies. Cell Death Differ 16:46-56.

Sequeiros J, Coutinho P (1993) Epidemiology and clinical aspects of Machado-Joseph disease. Adv Neurol 61:139-153.

Silva-Fernandes A, Costa Mdo C, Duarte-Silva S, Oliveira P, Botelho CM, Martins L, Mariz JA, Ferreira T, Ribeiro F, Correia-Neves M, Costa C, Maciel P (2010) Motor uncoordination and neuropathology in a transgenic mouse model of MachadoJoseph disease lacking intranuclear inclusions and ataxin-3 cleavage products. Neurobiol Dis 40:163-176.

Silva-Fernandes A, Duarte-Silva S, Neves-Carvalho A, Amorim M, Soares-Cunha C, Oliveira P, Thirstrup K, Teixeira-Castro A, Maciel P (2014a) Chronic treatment with 17-DMAG improves balance and coordination in a new mouse model of MachadoJoseph disease. Neurotherapeutics 11:433-449.

Silva-Fernandes A, Duarte-Silva S, Neves-Carvalho A, Amorim M, Soares-Cunha C, Oliveira P, Thirstrup K, Teixeira-Castro A, Maciel P (2014b) Chronic treatment with 17-DMAG improves balance and coordination in a new mouse model of MachadoJoseph disease. Neurotherapeutics.

Spilman P, Podlutskaya N, Hart MJ, Debnath J, Gorostiza O, Bredesen D, Richardson A, Strong R, Galvan V (2010) Inhibition of mTOR by rapamycin abolishes cognitive deficits and reduces amyloid-beta levels in a mouse model of Alzheimer's disease. PloS One 5:e9979.

Stambolic V, Ruel L, Woodgett JR (1996) Lithium inhibits glycogen synthase kinase- 3 activity and mimics wingless signalling in intact cells. Curr Biol 6:1664-1668.

Teixeira-Castro A, Ailion M, Jalles A, Brignull HR, Vilaca JL, Dias N, Rodrigues $\mathrm{P}$, Oliveira JF, Neves-Carvalho A, Morimoto RI, Maciel $P$ (2011) Neuron-specific proteotoxicity of mutant ataxin-3 in $C$. elegans: rescue by the DAF-16 and HSF-1 pathways. Hum Mol Genet 20:2996-3009.

Watase K, Gatchel JR, Sun Y, Emamian E, Atkinson R, Richman R, Mizusawa H, Orr HT, Shaw C, Zoghbi HY (2007) Lithium therapy improves neurological function and hippocampal dendritic arborization in a spinocerebellar ataxia type 1 mouse model. PLoS Med 4:e182.

Winklhofer KF, Tatzelt J, Haass C (2008) The two faces of protein misfolding: gain- and loss-of-function in neurodegenerative diseases. EMBO J 27:336-349.

Wolozin B, Behl C (2000) Mechanisms of neurodegenerative disorders: Part 1: protein aggregates. Arch Neurol 57:793-796.

Wood NI, Morton AJ (2003) Chronic lithium chloride treatment has variable effects on motor behaviour and survival of mice transgenic for the Huntington's disease mutation. Brain Res Bull 61:375-383.

Yu WH, Cuervo AM, Kumar A, Peterhoff CM, Schmidt SD, Lee JH, Mohan PS, Mercken M, Farmery MR, Tjernberg LO, Jiang Y, Duff K, Uchiyama Y, Nalund J, Mathews PM, Cataldo AM, Nixon RA (2005) Macroautophagy - a novel beta-amyloid peptidegenerating pathway activated in Alzheimer's disease. J Cell Biol 171:87-98.

Zhang L, Yu J, Pan H, Hu P, Hao Y, Cai W, Zhu H, Yu AD, Xie X, Ma D, Yuan J (2007) Small molecule regulators of autophagy identified by an image-based high-throughput screen. Proc Natl Acad Sci U S A 104:19023-19028. 